\title{
Managing change or changing management: climate change and human use in Kosciuszko National Park
}

\author{
C. Wyborn*
}

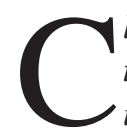
limate change is now widely accepted as a key threatening process to biodiversity conservation in national parks. In alpine Australia, some of these effects are already evident, as park managers come to terms with increased threats from large-scale fires and noticeable reductions in annual snow depth and cover. At the same time, businesses are expanding into year-round recreation and tourism, increasing the demand on park agencies to manage visitor needs and impacts. These changes, which transform both the ecology and the human use of alpine parks, will present many challenges to management. While extensive research is being conducted on the impacts of climate change to biophysical systems in national parks, climate change is rarely considered in the broader context of long-standing debates that polarise human use and conservation in parks. Through a qualitative case study of perceptions of climate change in Kosciuszko National Park (KNP), this article suggests that the human use versus conservation dichotomy must be overcome. This article will illustrate how perceptions of, and attachments to, 'place' shape human interactions with a national park. It will discuss the role of myths and paradoxes as barriers to the acceptance of management decisions in KNP. The article suggests that, given the growing number of social and ecological challenges faced by park agencies, it is no longer useful to consider the biophysical and social aspects of national parks separately; rather they should be reconceptualised as complex social-ecological systems and managed as an integrated whole.

Keywords: Protected area management, climate change, social-ecological systems, Kosciuszko National Park, place

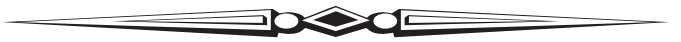

Managers of national parks in Australia face unprecedented challenges. The persistent issues of fire management and debates about fuel reduction burning, managing invasive and threatened species, and planning for climate change continue while park agencies attempt

* Carina Wyborn is with the Fenner School of Environment and Society, Australian National University, Canberra ACT 0200. Email: carina.wyborn@anu.edu.au. to meet growing expectations to increase visitor numbers encouraged by the 'Healthy Parks, Healthy People' program and an increased emphasis on nature-based tourism. The challenge of managing national parks is exacerbated by the apparent dichotomy of their role: are national parks a resource for human use or a resource for conservation?

This article suggests that, given the growing list of ecological and social management challenges, this is a false dichotomy. Instead, parks should be reconceptualised as complex social-ecological systems, and managed accordingly. An extensive body of literature on complex social-ecological systems (Boyden 1986; Gunderson et al. 1995; Berkes \& Folke 2000a; Gunderson \& Holling 2002; Walker \& Salt 2006; Kotchen \& Young 2007) indicates that separate understandings of natural and social systems are insufficient to appreciate the behaviour of the whole (Clark \& Dickson 2003), and supports instead a holistic investigation of a single, complex, interacting system. Fundamentally, a social-ecological perspective is concerned with relating management practices based in ecological understanding to the social mechanisms behind the practices and the feedbacks between the two systems (Berkes \& Folke 2000b).

This article uses a qualitative study of the perceptions of climate change in Kosciuszko National Park (KNP) to demonstrate how values, perceptions and expectations of ecosystems drive human interactions with the landscape. As climate change stresses the alpine environment, changes in the biophysical sphere are likely to exacerbate social tensions. Such qualitative research is important; the growing body of literature on climate change and protected area management (see Halpin 1997; Hannah et al. 2002, 2007; Scott et al. 2002; Suffling \& Scott 2002; Araújo et al. 2004; Araujo \& Rahbek 2006; Mansergh \& Cheal 2007; McDougall \& Broome 2007; Pickering 2007; Sutherst et al. 2007; Dunlop \& Brown 2008; Good 2008) clearly documents the impact of climate change on ecosystems, but rarely considers climate change in the context of social conflict over protected areas. In KNP, conflicts about the role of the park, permitted uses of the park, and highly emotive attachments to the area are challenges for those responsible for park management. 
The enduring nature of these challenges, and exacerbated tensions resulting from climate change, demonstrate the need for management change, towards a more integrated social-ecological system approach.

\section{Background}

Covering 690,411 hectares, KNP is one of the largest reserves in Australia (ISC 2004). It is managed by the NSW National Parks and Wildlife Service (NPWS), whose publicly stated aim is to work with local people and communities to protect and conserve natural and cultural heritage in the NSW landscape (DEC 2004). KNP is an area of biological and geomorphological significance recognised for its natural, scientific, cultural and recreational value (Good 1992; ISC 2004). With over 1.5 million visitors per year (Good 1995), it is an integral component of the regional economy (Roberts 2003). However, both winter and summer tourism and recreation, can affect native vegetation (Pickering et al. 2003; Pickering \& Hill 2007), so managing the impact of these visitors is a significant challenge (Crabb 2003; Pickering et al. 2003). Balancing the needs of users and conservation is not a new challenge in KNP; rather, conflicts are inextricably linked to the history of the region.

The history of the Australian alpine area has been identified in three distinct phases: Aboriginal preEuropean, European exploiter and European conserver (Lennon 1999). The transition between these phases led to the marginalisation of a group of people: the traditional owners were displaced by white settlers, who were then, after a protracted dispute, displaced first by hydro-engineers, then the national park. The creation of the national park divided the community into perceived winners (conservation groups) and losers (the grazing community). For the graziers, the creation of KNP led to a loss of employment, heritage and tradition. Despite efforts to develop relationships with this section of the community, 'a dogged minority still maintain their hatred of the park' (Hamilton-Smith 2004, p. 168).

These antagonisms have, to a certain degree, continued to this day (Read 1996; Hamilton-Smith 2004; Sullivan \&Lennon 2004), and the dispute has developed into a conflict over cultural and natural heritage that remains a part of managing KNP. A single narrative of this fraught period may never be agreed upon (for more detailed accounts, see Hancock 1972; Hueneke 1982, 1988; Mitchell 1985; Andrews 1991; Seddon 1994; Merritt 2007). However, it is important to acknowledge that the dispute was determined by complex interactions between science, politics, conservation and public expectations.
Over the past 200 years, land use changes in the area have mirrored shifting community perceptions, and the values and attitudes of the dominant, and indeed more powerful, voices in Australian society (NSW NPWS 2006; Merritt 2007).

While this conflict between natural and cultural heritage persists, climate change has been identified in the 2006 Plan Of Management (POM) as a key threat to the biodiversity and park values (NSW NPWS 2006), having been scarcely mentioned in previous editions of the POM. A number of Australian studies have discussed, observed and predicted impacts of climate change on snow conditions (Whetton 1998; Hennessy et al. 2003; Nicholls 2005; Edmonds et al. 2006), alpine biota (Pickering et al. 2004), and the ski industry (König 1998; Bicknell \& McManus 2006). These studies suggested that changes in temperature and precipitation will drive changes in the biophysical landscape and the ski industry. Some of these transformations are already being documented. This article does not detail these predictions and impacts but focuses on a qualitative study that aimed to discover and clarify the effects that such changes might have upon key users of the area.

\section{Methods}

Recent analysis of the social values of KNP indicated a lack of understanding of how people perceive and value the park experience (Hamilton-Smith 2004). Social research is required to fill this gap in understanding. Although large-scale, quantitative surveys would provide valuable information, a qualitative approach is also appropriate when a topic is emotional, complex or deeply rooted in the participants' personal knowledge of themselves (Ritchie 2003). As Popay et al. (1998, p. 341) pointed out, "there is a growing recognition that enlargement of our theoretical understanding of phenomena depends on the collection and interpretation of richer and deeper forms of data'. The focus of this study is to provide rich detail on a range of perspectives that park users and managers have, and to discover perceptions and concerns about climate change and park management.

Qualitative research does not claim to gain a representative sample or results that can be generalised to a broader population. Instead, the in-depth interviews provide a valuable insight into the perceptions and interpretations of selected individuals (Minichello et al. 1995). In this study, participants were selected using a key informant approach, which seeks to identify participants who will provide deeper insight into a given situation, based on their position, association or skills (Marshall 1996). The study did not aim to uncover the opinions of 
the majority of KNP users, nor did it aim to cover all possible perspectives; instead, it aimed to facilitate a deeper understanding of the complexities of the participants' perceptions than would be possible using a survey or population sample.

The participants included public interests:

- five mid-level staff members from the Jindabyne NPWS office (representing a range of roles, including operations, management, resort liaison, fire management and an Indigenous officer)

- three government scientists

and private interests:

- four commercial operators located within KNP (representing key commercial interests and recreational purists in the park: ski resorts, horse-riding and mountain-biking)

- five recreational users (respondents used KNP for multiple purposes of bushwalking, backcountry and downhill skiing, climbing, fishing, and illegal recreational hunting).

The division between public and private interests was intended to explore potential discrepancies between management and user expectations of KNP now and in the future. As most of the NPWS staff, scientists and commercial operators also use the park for recreation, recreational users are referred to as 'non-managers'. Based on their relationship with the NPWS and KNP as expressed in the interviews, two of these participants (a NPWS staff member and a commercial operator) were reclassified into a new category: excluded-users.

Respondents were questioned in semi-structured interviews about their perceptions of climate change in $\mathrm{KNP}$, their experience of KNP, their future expectations of KNP, and their perceptions of NPWS management of the park. The approach was guided by the methodology of Critical Systems Heuristics (CSH), a conceptual framework for promoting critical research practice (Ulrich 1983). The core of CSH is 12 questions, used to frame an inquiry, that address four key issues: values, power, knowledge and legitimacy. The approach can be used as an analytical tool by researchers or to facilitate dialogue in participatory processes (for further detail, see Wyborn \& Cleland in press).

A discussion group was held to triangulate the interviews; that is, to cross-check the integrity of the data collected (Ritchie 2003). Nine members of the Snowy Mountains Region Advisory Committee, a stakeholder consultation group run by the NPWS, were asked to discuss their perceptions of climate change in KNP and the role of the NPWS in managing this change. The perspectives from the discussion group followed the same themes as found in the interviews.

Interviews were recorded, transcribed verbatim and entered into the qualitative data analysis software NVivo 7. Transcripts and notes taken at the discussion group were coded according to themes, concepts and topics that emerged from the data (Bazeley 2007). Following adaptive theory (Layder 1998), the codes were not limited to preconceived theoretical ideas. After initial coding, key themes were identified and a second coding was conducted to refine and cross-check the findings. During this process, respondents were placed into five actor categories (see Table 1), which were used to facilitate a comparative analysis on the themes introduced by the interview questions.

\section{Results and discussion}

A data matrix (Miles \& Huberman 1994) placing respondents into actor categories was used to contextualise the data analysis and discussion (Table 1).

Information contained within this display and quotes used in this article were selected based on in-depth analysis of interview material and data matrices (Nadin \& Cassell 2004).

\section{Perceptions of climate change and KNP}

All respondents reported feeling connected to KNP. The majority first visited KNP in their childhood and universally agreed that it is a special place to which they would always return. This quote demonstrates a position held by many:

I'm not a spiritual person but it's quite a, you know, just the whole cliché, you get in touch with nature and get away from it all... I've seen a lot of beautiful places around the world and, when I've been away from the Snowies for a while, I always just crave being back in that alpine environment. I guess it feels like home (NM-03).

Regardless of the particularities of their relationship with the park, all respondents described their experiences and attachment to the area with the same sense of connection.

Respondents also all shared a concern about the impact of climate change on the place they loved.

I guess it's depressing to think that this was my little backyard and peoples' recreational areas all around Australia are going to be affected in different but equally bad ways (NM-03).

It is changing from the place that I knew as a kid and which you know in itself isn't necessarily a bad thing but, for me personally, I find it a little bit sad (NPWS-01). 
Table 1 Summary of actor groups

\begin{tabular}{|c|c|c|c|c|}
\hline & Descriptors & $\begin{array}{l}\text { Perception of } \\
\text { primary concerns } \\
\text { of the NPWS }\end{array}$ & $\begin{array}{l}\text { Expectations of } \\
\text { NPWS }\end{array}$ & $\begin{array}{l}\text { Criticism of } \\
\text { NPWS }\end{array}$ \\
\hline $\begin{array}{l}\text { NPWS staff } \\
(N=4)\end{array}$ & $\begin{array}{l}\text { Between 2-20 } \\
\text { years } \\
\text { experience in } \\
\text { NPWS }\end{array}$ & $\begin{array}{l}\text { Fire, weeds, pests, } \\
\text { threatened species, } \\
\text { community } \\
\text { relations }\end{array}$ & $\begin{array}{l}\text { Community } \\
\text { relations and } \\
\text { diverse community } \\
\text { interests their most } \\
\text { significant } \\
\text { challenge }\end{array}$ & $\begin{array}{l}\text { Need to manage for } \\
\text { political climate }\end{array}$ \\
\hline $\begin{array}{l}\text { Government } \\
\text { scientists (GS) } \\
(\mathrm{N}=\mathbf{3})\end{array}$ & $\begin{array}{l}\text { Long } \\
\text { involvement } \\
\text { with KNP, two } \\
\text { ex-staff, one } \\
\text { NSW } \\
\text { government } \\
\text { employee }\end{array}$ & $\begin{array}{l}\text { Balancing } \\
\text { conservation with } \\
\text { recreation, } \\
\text { managing } \\
\text { visitation, fire }\end{array}$ & $\begin{array}{l}\text { Adaptive } \\
\text { management, } \\
\text { monitoring, } \\
\text { research, } \\
\text { community } \\
\text { consultation }\end{array}$ & $\begin{array}{l}\text { Sympathetic to the } \\
\text { challenges faced by } \\
\text { NPWS, also } \\
\text { discussed } \\
\text { managing for } \\
\text { political climate }\end{array}$ \\
\hline $\begin{array}{l}\text { Commercial } \\
\text { operators (CO) } \\
(\mathrm{N}=3)\end{array}$ & $\begin{array}{l}\text { Reside in KNP, } \\
\text { activities } \\
\text { determined by } \\
\text { NPWS }\end{array}$ & $\begin{array}{l}\text { NPWS overly } \\
\text { conservation- } \\
\text { focused }\end{array}$ & $\begin{array}{l}\text { Research, } \\
\text { monitory, } \\
\text { education, tourism }\end{array}$ & $\begin{array}{l}\text { Poor } \\
\text { communication } \\
\text { strategies, } \\
\text { community } \\
\text { consultation }\end{array}$ \\
\hline $\begin{array}{l}\text { Excluded users } \\
(\mathrm{EU})(\mathrm{N}=2)\end{array}$ & $\begin{array}{l}\text { Indigenous } \\
\text { Traditional } \\
\text { Owner, grazier }\end{array}$ & $\begin{array}{l}\text { Development of } \\
\text { tourism } \\
\text { infrastructure } \\
(\mathrm{N}=1) \text {, satisfying } \\
\text { green political } \\
\text { agenda }(\mathrm{N}=1)\end{array}$ & $\begin{array}{l}\text { Refocus on } \\
\text { practical } \\
\text { management, better } \\
\text { consultation with } \\
\text { their communities, } \\
\text { ability to practise } \\
\text { cultural heritage in } \\
\text { the park }\end{array}$ & $\begin{array}{l}\text { Poor } \\
\text { communication, } \\
\text { inadequate } \\
\text { consultation, lack } \\
\text { of respect for } \\
\text { cultural heritage }\end{array}$ \\
\hline $\begin{array}{l}\text { Non-managers } \\
(\mathrm{NM})(\mathrm{N}=\mathbf{5})\end{array}$ & $\begin{array}{l}\text { Range of } \\
\text { recreational } \\
\text { purists and } \\
\text { ages, all from } \\
\text { Canberra region }\end{array}$ & $\begin{array}{l}\text { Biodiversity } \\
\text { conservation, fire } \\
\text { management }\end{array}$ & $\begin{array}{l}\text { Conservation, } \\
\text { climate change, } \\
\text { monitoring and } \\
\text { research }\end{array}$ & $\begin{array}{l}\text { Less critical than } \\
\text { EU and CO, some } \\
\text { complaints about } \\
\text { poor } \\
\text { communication }\end{array}$ \\
\hline
\end{tabular}

As these quotes illustrate, climate change often invoked an emotional response. Respondents believed that, in a warmer climate, there would be a gradual increase in the elevation of the snowline, a decline in precipitation, and an increased risk of large-scale fires. Some participants $(\mathrm{N}=9)$ believed that the run of poor snow seasons, and the 2003 fires, were signs that climate change has begun to affect the park. All respondents, except one who did not believe in climate change, were concerned about future climate change, believing that it would increasingly be an issue that the NPWS would have to integrate into all facets of management. Climate change would not prevent respondents from visiting the park in the future; however, for a small number it would detract from their enjoyment of the area. Given this, respondents expected the NPWS to respond to their concern by taking whatever course of action is necessary.

Although respondents expressed concern about the future implications of climate change, it has not yet created the divisions similar to issues of the 'here and now'. Despite a shared attachment to KNP, divergent expectations emerged over how the park should be used and managed in the present. These tensions are indicative of the conflict between conservation and human use that originated when KNP was created. The complexity presented in the remainder of this article is the arena in which climate change processes will unfold. Current management issues cannot be divorced from climate change adaptation strategies (Dovers 2009). Indeed, they must be addressed in light of the complexities that climate change will present in the future.

\section{Conflicting legislative mandate}

The conflict between conservation, cultural heritage and recreation is enshrined in the legislation that defines a national park in New South Wales.

The purpose of reserving land as a national park is to identify, protect and conserve areas containing outstanding or representative ecosystems, natural or cultural features or landscapes or phenomena that provide opportunities for public appreciation and inspiration and sustainable visitor use and enjoyment... (NSW National Parks and Wildlife Act 1974, s. 30e).

The human use aspect necessitates consideration of the wishes, expectations, values and relationships that visitors hold for national parks (Beeton 1999). While in some cases these motivations can co-exist, the history of KNP illustrates that this tension is also a source of conflict; and there is an emerging recognition of the negative human impact of tourism and recreation on vegetation (see Pickering \& Buckley 2003; Pickering et al. 2003; Pickering \& Hill 2007). This conflict is embodied in the following quote:

The whole place has been torn apart by all these people who want a bit of it. So there has to be a compromise all the time (NM-04).

Unless the legislation is changed, the guiding intention of a national park will be to manage this tension suggesting that effective management of this conflict will depend on overcoming such divergent understandings.

Multiple values posited on a national park can be partially attributed to the generalised wording of the 
Table 2 Respondents' perceptions of the purpose of a national park

\begin{tabular}{lllll}
\hline $\begin{array}{l}\text { Commercial } \\
\text { operator }\end{array}$ & Non-manager & NPWS staff & $\begin{array}{l}\text { Government } \\
\text { scientist }\end{array}$ & Excluded users \\
\hline $\begin{array}{l}\text { Sustainable } \\
\text { recreation and } \\
\text { conservation as } \\
\text { twin pillars }\end{array}$ & $\begin{array}{l}\text { Preservation of } \\
\text { the environment }\end{array}$ & $\begin{array}{l}\text { Preservation and } \\
\text { access which } \\
\text { means balancing }\end{array}$ & $\begin{array}{l}\text { Catchment } \\
\text { management, } \\
\text { conservation and } \\
\text { conservation and } \\
\text { recreation }\end{array}$ & $\begin{array}{l}\text { now recreation } \\
\text { environment and } \\
\text { recreation. Should also } \\
\text { enable lived cultural } \\
\text { heritage }\end{array}$ \\
\hline
\end{tabular}

'special place', an attachment illustrated by the following quote:

It is the most beautiful part of Australia and one of the most beautiful parts of the world. It would have to change a lot for me to stay away from the place (NPWS-02).

Connections to landscapes are legislation. A lack of agreement between the NPWS and the NSW community over the role and function of conservation reserves creates a source of conflict over park management plans (Smith 1998). While the respondents agreed that conservation was integral to a national park, their positions existed on a continuum from believing in conservation for intrinsic purposes to conservation for the enjoyment of current and future generations (see Table 2). These findings support Recher's (1998, p. 135) claim that 'the public perception of a national park is one of a recreation area, albeit with conservation values'. Each user group appreciates the different values of KNP in different ways, and, as Kuentzel and Dennis (1998 in Borrie et al. 2002) suggested, much of the controversy in environmental management is due to various constituencies valuing specific amenities differently. Under legislation of this scope, competing interest groups promote their right to use a national park as they please and can justify the legality of their activity. Hence, conflict emerges as various players seek to enjoy contradictory aspects of a geographically-confined space that is underpinned by a conservation imperative.

While these disagreements are widely recognised as existing between those associated with national parks, this conflict also emerged within the individuals themselves. The following quotes are from the same person; the first is his idea of KNP as a national park, while the second quote is his perspective on his ability to engage with the area now and in the future.

It's a unique area, it should be a national park. And it should be looked after with the values that... the conservation of the environment is the most important thing, everything happens after that.

As long as I'm allowed to do what I want, I'm happy (CO-02).

This disjunction was common across respondents. When asked about the purpose of a national park, they spoke in generalities of conservation, recreation and cultural heritage. However, when asked how they wished to engage with the specific locale of KNP, they sought a continuation of their previous experiences and memories. All respondents agreed that the area was a 'multifaceted, complex and saturated with meaning'; they are neither logical, rational nor amenable to measurement and quantification (Cheng et al. 2003, p. 90). Attachments to place are deeply ingrained in those who hold them (Williams \& Stewart 1998), and can influence an individual's openness to rules and regulations imposed on that place (Cheng et al. 2003). In the case of KNP, attachments to the park are entirely independent of legislative notions of its role as a 'national park'. Such conflicts within individuals represent the disjunction between the formal definition of a national park and individuals' lived experiences of the park.

Paradoxically, given that KNP is a national park in a democratic nation, issues of ownership and rights complicate assertions of what is acceptable behaviour. As public land, national parks are areas that individuals, as part of their democratic rights, are authorised to enjoy. If the park's constituents perceive KNP as a space for conservation and recreation (i.e. public pleasure), then visitor restrictions would be a violation of their perception of the park's purpose.

Social and political processes shape notions of acceptable behaviour in a place; moreover, different groups of people are likely to have different definitions of acceptable behaviour on public land (Cheng et al. 2003). To crudely summarise the respondents' responses,

I do $\mathrm{x}$ in that geographic locale, an area that I love and have strong attachments to. I should be allowed to continue to do so because it is a national park and it is my democratic right to enjoy it.

The continuation of the respondents' relationship with KNP is independent of the legislated purposes of a national park. Yet, the notion and label of 'national' reinforces the idea that people are allowed to engage with that space - that area that they love and have a strong attachment to - in whatever manner they choose, even if it threatens what they see as the primary purpose of a 'national park', that is, the conservation of biodiversity. This finding has important implications for the NPWS planning process. It suggests that the NPWS staff and those involved in the community consultation are coming together to discuss the management of different ideals: what it is to be a national park (which is contested in 
itself); and what it is for people to use 'their place', regardless of its legal status.

\section{Perceptions of the NPWS}

The following quotes are illustrative of four myths about the NPWS (in the KNP region) and the organisation's motives that emerged through this research:

- The NPWS is opposed to ski resorts in KNP.

The national park service is rubbing their hands with glee that there seems to be less snow in the ski season. It's a fairly well known phenomenon that the national park's way of managing the alpine area is to just shut everybody out, manage by exclusion rather than manage visitation directly; so I think they go yahoo (CO-02).

- The NPWS manage to exclude people from the alpine and other areas of KNP.

I think the national parks very much (sic) has the mentality at the moment of lock it up and keep people out (NM-01).

- The NPWS, and the creation of KNP, was responsible for the cessation of grazing in KNP. ${ }^{1}$

There is a whole culture around the mountain people... we are progressively being kicked out (EU-01).

- The NPWS manage for their interests, rather than the interests of user groups.

I probably don't agree with a lot of their decisions because they probably accept the advice of their staff more so than the advice of their stakeholders (CO-01).

Each of these myths was contradicted by the NPWS staff, confirming Hamilton-Smith's (2004) claims that park managers' values are often misunderstood by the public. The relative 'truth' of the myths is entirely subjective and to a degree irrelevant because sections of the community believe them to be true and shape their perceptions of the NPWS accordingly. These myths are not only evidence of strained community relations, but serve as a barrier to effective communication between the NPWS and its constituency, as the perception of a secret agenda, correct or not, is detrimental to a planning process (Kaltenborn et al. 1999). Despite claims by NPWS staff that community relations were among the most important aspects of their job, a strong perception that the NPWS staff are poor communicators emerged in this study, as illustrated by the following quotes:
I don't know what they do, they don't communicate it. They are very insular and inward thinking (CO-02).

They don't like to communicate on the field, it's like their fire and there is a lot of just stupid, cagey behaviour. They are not sharing information and this because it is them and us, if you know what I mean (NM-04).

This is mirrored by the challenges of communicating with the public emphasised by the NPWS staff:

I don't know if we really know enough about what the broader population really want (NPWS-03).

This poor communication with stakeholders is likely to reinforce the proliferation of myths, which in turn influences the acceptance of management decisions. These myths present an interesting challenge for the NPWS, which must respond to public perceptions of erroneous management strategies.

Strained community relations and a perception of poor communication presents a major obstacle to effective park management in the future, including on issues such as climate change. To fulfil commitments to protect biodiversity under climate change processes, management regimes may need to change (Dunlop \& Brown 2008). Whether preventative or reactive, this could lead to restrictions on visitor access. The NPWS staff said that they would only support restrictions if backed by 'solid science'; however, if restrictions eventuate, excellent communication strategies and community relations will be required to communicate that science. To quote a respondent, it may become difficult to "persuade ... [a] cranky public or some increasingly cranky people to go along with this and not to make a fuss' (NM-02). Further, the search for solid science to back management decisions is problematic; even as the details of climate predictions for the region improve, the potential impacts of climatic changes on the social-ecological system will remain uncertain.

There was considerable speculation among respondents that the threat and risk of high intensity fires would increase in a hotter, drier future. The 2003 fires which, according to the non-managers, 'devastated' aspects and areas of KNP provide insight into this future. After these fires, sections of the park were closed for rehabilitation; and respondents speculated that, in a future of increased fire frequency, such closures could become more common. One respondent - a non-manager (NM-01) who

\footnotetext{
${ }^{1}$ The termination of grazing has been attributed to a number of factors, most commonly the creation of the park system. Arguably, it was the culmination of many influences including, but not limited to, a concern for soil conservation; erosion of the catchment head-waters of the Snowy Mountains Hydro-Electric Scheme; onfarm improvements in the Monaro reducing the need for relief grazing; and a social impetus for conservation, tourism and recreation (Seddon 1994; Read 1996; Merritt 2007). See Merritt's Losing Ground (2007) for a detailed account of the period, which posits the construction of the hydro-electric scheme as the most influential factor.
} 
was not affiliated with the section of the public that is commonly perceived to be hostile towards the NPWS believed that the park service was using fire rehabilitation as an excuse to keep people out of certain areas. $\mathrm{He}$ attributed this to a 'lock-up mentality' of the agency, which he perceived to be insular and overly conservationfocused. This belief demonstrates a mistrust of the motives of the NPWS and illustrates how old conflicts become embedded in new situations. Without adequate communication, the myths come into play and reinforce the negative perceptions of the park service. This example demonstrates how the feedbacks within the socialecological system could be exacerbated by climate change.

\section{High expectations placed on national parks}

In light of the complexity associated with balancing conservation and recreation, this section will discuss briefly the high expectations placed on the national park system. As discussed, the legislation states that parks are areas for cultural heritage, natural heritage and recreation. While protected area legislation is often written in vague language to accommodate various interests (McCool \& Stankey 2004), such generalities do not make the task of managing diverse interests any easier. Despite contrasting expectations of KNP and its management, decisions have to be made. Because of the democratic system, KNP is not managed solely on scientific principles and is required, by statute, to balance conservation and human use. This tension is illustrated by the following quotes:

You can end up being forced to do the wrong thing because you're part of a democratic process and so you have to do what people want (NPWS-01).

[NPWS] can't run like a dictatorship you know, and if they tried to, you wouldn't have a job much longer (NPWS-02).

As the agency with the power to make decisions, the NPWS is required to synthesise a coherent management framework from the contrasting perspectives of stakeholder groups. Tradeoffs need to be made and, to a degree, they are. In Canada, the issue of a dual mandate for visitor use and environmental protection was resolved in amendments to the Canadian National Parks Act in 1988 that placed ecological integrity as the primary objective of park management (Scott et al. 2002). Perhaps it is time for NSW and Australia to consider specifying a primary objective for our national parks. Further inquiry into, and deliberation on, the purpose of a national park may strengthen policy to assist both management and the park's constituency to make informed judgements that integrate or balance various expectations (Brunner 2002).

\section{Conclusion}

This article proposes that the human use versus conservation dichotomy is a false division. On one level, it could be argued that climate change would be the domain of the biophysical management side of the NPWS, while visitor management and expectations should be managed by the community liaison section. Yet, in KNP, we find two pressures acting on the same system at the same time. The example of fire management and visitation demonstrates how the feedbacks and interactions between these two pressures within the system have important implications for management. In order to fully appreciate these feedbacks, interacting variables must be considered in the context of the whole social-ecological system. The biophysical process of climate change will influence human behaviour in the KNP, which will in turn feed back to the biophysical system through human impacts and expectations on the landscape.

The threat that climate change presents to alpine ecosystems may significantly undermine the legislated responsibility of the NPWS to protect and conserve representative ecosystems and natural heritage. The success of future conservation efforts is, however, unlikely to be solely limited by the science of conservation biology. To quote a NPWS staff member, '[t]he key to all national parks lies in the hands of [the] mainstream community' (EU-02). The future of multipleuse national parks will be contingent on the values and expectations of the community as manifested through funding, or the extent to which park visitors accept restrictions on their recreational pleasure. Despite the power of the NPWS to determine the rules of engagement, rangers are not able to supervise all visitor behaviour and, once inside the park, an individual has considerable capacity to behave as they choose. Park management is about managing people, but the conservation imperative requires scientific foundations of management. These are not issues for purely biophysical or purely social research; rather, they need to be understood as multiple, interacting variables in a complex system.

Climate change may disturb current biophysical and social relations, but now, more than ever, the public is concerned about climate change and what it means for the future of places like KNP. The tensions outlined in this article are as old as the park itself, yet they continue to persist. Perhaps current concern about climate change could be harnessed to try a new management strategy, or at least a new communication strategy. 
Misunderstandings of the multiple purposes of a national park, or of the motives of the NPWS, present a significant barrier to effective communication. Communicating the rational behind management decisions may not convince park users to agree with the NPWS. Nonetheless, it could guard against the proliferation of myths about their management strategies, and improve the public perception of the NPWS and its actions.

Rather than manage parks with an 'ecology first' or 'people first' perspective, I suggest that national parks should be reconceptualised as complex social-ecological systems. This would entail management that focuses on the interactions and connections between park users, local communities, management activity and the ecosystem as a whole. It will require interdisciplinary perspectives and knowledge generated from outside academia, as well as both the social and biophysical sciences, to grapple with the multi-layered complexities associated with park management. As the importance of biodiversity conservation accelerates, national parks will continue to be situated within a local community, managed by people, and be places that are loved and visited by those who live near and far. Management will, by necessity, be required to grapple with both shared and conflicting values, as well as the intersection of the social and biophysical worlds.

\section{Acknowledgments}

Thank you to David Dumaresq, Geraldine Li and Stephen Dovers for assistance throughout this research and comments on draft versions of this article. Thank you also to two anonymous reviews for their comments and suggestions, and to Ruth Pitt for her assistance with the final manuscript.

\section{References}

Andrews, A 1991, Kosciuszko: the mountain in history, Tabletop Press, Canberra.

Araújo, M, Cabeza, M, Thuiller, W, Hannah, L \& Williams, P 2004, 'Would climate change drive species out of reserves? An assessment of existing reserve-selection methods', Global Change Biology, vol. 10, no. 9, pp. 1618-1626.

Araujo, MB \& Rahbek, C 2006, 'How does climate change affect biodiversity?', Science, vol. 313, no. 5792, pp. 13961397.

Bazeley, P 2007, Qualitative data analysis with NVIVO, Sage Publications, London.

Beeton, S 1999, 'Hoof prints on the mind: an exploration of attitudinal relationships between bushwalkers and commercial horseback tours', Tourism Management, vol. 20, pp. 255-259.
Berkes, F \& Folke, C (eds) 2000a, Linking social and ecological systems: management practices and social mechanisms for building resilience, Cambridge University Press, Cambridge.

Berkes, F \& Folke, C 2000b, 'Linking social and ecological systems for resilience and sustainability', in F Berkes \& C Folke (eds), Linking social and ecological systems: management practices and social mechanisms for building resilience, Cambridge University Press, Cambridge, pp. 1-26.

Bicknell, S \& McManus, P 2006, 'The canary in the coalmine: Australian ski resorts and their response to climate change', Geographical Research, vol. 44, no. 4, pp. 386-400.

Borrie, W, Freimund, W \& Davenport, M 2002, 'Winter visitors to Yellowstone National Park: their value orientations and support for management actions', Human Ecology Review, vol. 9, no. 2, pp. 41-48.

Boyden, S 1986, 'An integrative approach to the study of human ecology', in RJ Borden, J Jacobs \& GL Young (eds), Human ecology: a gathering of perspectives, The Society for Human Ecology, College Park, Maryland, USA, pp. 3-25.

Brunner, R 2002, 'Problems of governance', in R Brunner, CH Colburn, CM Cromley, RA Klein \& EA Olsen (eds), Finding common ground: governance and natural resources in the American west, Yale University Press, New Haven, Connecticut, USA, pp. 1-47.

Cheng, A, Kruger, L \& Daniels, S, 2003, 'Place as an integrating concept in natural resource politics: propositions for a social science agenda', Society and Natural Resources, vol. 16, no. 2, pp. 87-104.

Clark, WC \& Dickson, NM 2003, 'Sustainability science: the emerging research program', Proceedings of the National Academy of Sciences of the United States of America, vol. 100, no. 14, pp. 8059-8061.

Crabb, P 2003, Managing the Australian Alps: a history of cooperative management of the Australian Alps national parks, Centre for Resource and Environmental Studies, ANU \& the Australian Alps Liaison Committee, Canberra.

DEC (Department of Environment and Conservation) 2004, State of the Parks 2004, DEC, Sydney.

Dovers, S 2009, 'Normalizing adaptation', Global Environmental Change, vol. 19, no. 1, pp. 4-6.

Dunlop, M \& Brown, PR 2008, Implications of climate change for Australia's National Reserve System: a preliminary assessment, report to the Department of Climate Change, February 2008, Department of Climate Change, Canberra.

Edmonds, T, Lunt, ID, Roshier, DA \& Louis, J 2006, 'Annual variation in the distribution of summer snowdrifts in the Kosciuszko alpine area, Australia, and its effect on the composition and structure of alpine vegetation', Austral Ecology, vol. 31, no. 7, pp. 837-848.

Good, RB 1992, Kosciuszko heritage: the conservation significance of Kosciuszko National Park, NSW National Parks and Wildlife Service, Sydney. 
Good, RB 1995, 'Ecologically sustainable development in the Australian Alps', Mountain Research and Development, vol. 15, pp. 251-258.

Good, RB 2008, 'Management adaptations to climate change impacts in the alpine area', in $\mathrm{K} \mathrm{McCue} \mathrm{\&} \mathrm{S} \mathrm{Lenz} \mathrm{(eds),}$ Corridors for survival in a changing world, Proceedings of the National Parks Association of the ACT symposium, 9-10 May 2008, Canberra, National Parks Association of the ACT, Canberra, pp. 29-24.

Gunderson, LH \& Holling, CS (eds) 2002, Panarchy, Island Press, Washington DC.

Gunderson, LH, Holling, CS \& Light, SS (eds) 1995, Barriers and bridges to the renewal of ecosystems and institutions, Columbia University Press, New York.

Halpin, PN 1997, 'Global climate change and natural-area protection: management responses and research directions', Ecological Applications, vol. 7, no. 3, pp. 828-843.

Hamilton-Smith, E 2004, 'Social values', in Independent Scientific Committee (ed.), An assessment of the values of Kosciuszko National Park, NSW NPWS, Queanbeyan, New South Wales, pp. 163-177.

Hancock, W 1972, Discovering Monaro: a study of man's impact on his environment, Cambridge University Press, London.

Hannah, L, Midgley, G \& Millar, D 2002, 'Climate changeintegrated conservation strategies', Global Ecology and Biogeography, vol. 11, no. 6, pp. 485-495.

Hannah, L, Midgley, G, Andelman, S, Araujo, M, Hughes, G, Martinez-Meyer, E, Pearson, R \& Williams, P 2007, 'Protected area needs in a changing climate', Frontiers in Ecology and the Environment, vol. 5, no. 3, pp. 131-138.

Hennessy, HJ, Whetton, PH, Smith, IN, Bathols, JM, Hutchinson, MF \& Sharples, JJ 2003, Climate change impacts on snow conditions in Australia, CSIRO \& the Centre for Resources and Environmental Studies, Australian National University, Canberra.

Hueneke, K 1982, Huts of the high country, ANU Press, Canberra.

Hueneke, K 1988, Kiandra to Kosciuszko, Tabletop Press, Canberra.

ISC (Independent Scientific Committee) (ed.) 2004, An assessment of the Kosciuszko National Park values: final report of the Independent Scientific Committee, NSW NPWS, Queanbeyan, New South Wales.

Kaltenborn, BP, Riese, H \& Michael, H 1999, 'National park planning and local participation: some reflections from a mountain region in southern Norway', Mountain Research and Development, vol. 19, no. 1, pp. 51-61.

König, U 1998, 'Climate change and the Australian ski industry', in K Green (ed.), Snow: a natural history; an uncertain future, Australian Alps Liaison Committee, Canberra, pp. 207-223.

Kotchen, MJ \& Young, OR 2007, 'Meeting the challenges of the Anthropocene: towards a science of coupled human- biophysical systems', Global Environmental Change, vol. 17, no. 2 , pp. 149-151.

Kuentzel, W \& Dennis, D1998, 'Landowner values, water quality, and recreation in the Lake Champlain Basin', in HG Vogelsong (ed.), Proceedings of the 1997 Northeastern Recreation Research Symposium, 6-9 April 1997, Bolton Landing, New York, Gen. Tech. Report NE-241, US Department of Agriculture, Forest Service, Northeastern Forest Experiment Station, Radnor, Pennsylvania, USA, pp. 155-162.

Layder, D 1998, Sociological practice: linking theory and social research, Sage Publications, London.

Lennon, JL 1999, The international significance of the cultural values of the Australian Alps, Jane Lennon and Associates, Melbourne.

Mansergh, I \& Cheal, D 2007, 'Protected area planning and management for eastern Australian temperate forests and woodland ecosystems under climate change - a landscape approach', in M Taylor \& P Figgis P (eds), Protected areas: buffering nature against climate change, Proceedings of a WWF \& IUCN World Commission on Protected Areas symposium, 18-19 June 2007, Canberra, WWF-Australia, Sydney, pp. 58-72.

Marshall, M 1996, 'The key informant technique', Family Practice, vol. 13, pp. 92-97.

McCool, SF \& Stankey, GH 2004, 'Advancing the dialogue of visitor management: expanding beyond the culture of technical control', in D Hammon, B Kilgore \& GE Vietzke (eds), Protecting our diverse heritage: the role of parks, protected areas and cultural sites, Proceedings of the 2003 George Wright Society/National Park Service joint conference, 14-18 April 2003, San Diego, California, the George Wright Society, Hancock, Michigan, pp. 122-127.

McDougall, K \& Broome, L 2007, 'Challenges facing protected area planning in the Australian Alps in a changing climate', in M Taylor \& P Figgis (eds), Protected areas: buffering nature against climate change, Proceedings of a WWF \& IUCN World Commission on Protected Areas symposium, 18-19 June 2007, Canberra, WWF-Australia, Sydney.

Merritt, J 2007, Losing ground: grazing in the Snowy Mountains 1944-1969, Turalla Press, Canberra.

Miles, M \& Huberman, A 1994, Qualitative data analysis: an expanded sourcebook, second edition, Sage Publications, Thousand Oaks, California.

Minichiello, V, Aroni, R, Timewll, E \& Alexander, L 1995, Indepth interviewing: principles, techniques, analysis, second edition, Longman, Melbourne.

Mitchell, E 1985, Discoverers of the Snowy Mountains, McMillan, Melbourne.

Nadin, S \& Cassell, C 2004, 'Using data matrices', in C Cassell \& G Symon (eds), Essential guide to qualitative methods in organisational research, Sage Publications, London.

Nicholls, N 2005, 'Climate variability, climate change and the Australian snow season', The Australian Meteorological Magazine, vol. 53, no. 3, pp. 177-185. 
NSW NPWS (National Parks and Wildlife Service) 2006, Kosciuszko National Park plan of management, NSW Department of Environment and Conservation, Sydney.

Pickering, C 2007, 'Climate change and other threats in the Australian Alps', in M Taylor \& P Figgis (eds), Protected areas: buffering nature against climate change, Proceedings of a WWF \& IUCN World Commission on Protected Areas symposium, 18-19 June 2007, Canberra, WWF-Australia, Sydney.

Pickering, C \& Buckley, R 2003, 'Swarming to the summit', Mountain Research and Development, vol. 23, no. 3, pp. 230233.

Pickering, C, Good, RB \& Green, K 2004, Potential effects of global warming on the biota of the Australian Alps, Australian Greenhouse Office, Canberra.

Pickering, C, Harrington, J \& Worboys, G 2003, 'Environmental impacts of tourism on the Australian Alps protected areas', Mountain Research and Development, vol. 23, no. 3, pp. 247-254.

Pickering, C \& Hill, W 2007, 'Impacts of recreation and tourism on plant biodiversity and vegetation in protected areas in Australia', Journal of Environmental Management, vol. 85, pp. 791-800.

Popay, J, Rogers, A \& Williams, G 1998, 'Rationale and standards for the systematic review of qualitative literature in health services research', Qualitative Health Research, vol. 8, no. 3, pp. 341-351.

Read, P 1996, Returning to nothing: the meaning of lost places, Cambridge University Press, Melbourne.

Recher, HF 1998, 'Parks for biodiversity: an old and tarnished vision', in P Prineas (ed.), National parks: new visions for a new century, Proceedings of the Paddy Pallin conference, 18-19 July 1997, Sydney, Nature Conservation Council of NSW, Sydney, pp. 128-139.

Ritchie, J 2003, 'The application of qualitative methods to social research', in J Ritchie \& J Lewis (eds), Qualitative research practice: a guide for social science students and researchers, Sage Publications, London, pp. 24-46.

Roberts, G 2003, 'Can the mountains survive without tourism?', in Celebrating mountains: proceedings of an International Year of Mountains conference, 25-28 November 2002, Jindabyne, New South Wales, Australian Alps Liaison Committee, Canberra, pp. 157-162.

Scott, D, Jay, R \& Lemieux, C 2002, 'Climate change and modelled biome representation in Canada's national park system: implications for system planning and park mandates', Global Ecology and Biogeography, vol. 11, no. 6, pp. 475-484.

Seddon, G 1994, Searching for the Snowy: an environmental history, Allen and Unwin, Sydney.

Smith, S 1998, National parks in New South Wales, NSW Parliamentary Library Research Service Briefing Paper no. 22/98, Parliament of NSW, Sydney.
Suffling, R \& Scott, D 2002, 'Assessment of climate change effects on Canada's national park system', Environmental Monitoring and Assessment, vol. 74, no. 2, pp. 117-139.

Sullivan, S \& Lennon, JL 2004, 'Cultural values', in Independent Scientific Committee (ed.), An assessment of the values of Kosciuszko National Park, NSW National Parks and Wildlife Service, Queanbeyan, New South Wales, pp. 129-162.

Sutherst, RW, Backer, RHA, Coakley, SM, Harrington, R, Kriticos, DJ \& Scherm, H 2007, 'Pests under global change meeting your future landlords', in JG Cannadell, DE Pataki \& LF Pitelka (eds), Terrestrial ecosystems in a changing world, Springer, Berlin, pp. 211-226.

Ulrich, W 1983, Critical heuristics of social planning: a new approach to practical philosophy, Wiley, Bern, Switzerland.

Walker, B \& Salt, D 2006, Resilience thinking: sustaining ecosystems and people in a changing world, Island Press, Washington DC.

Whetton, P 1998, 'Climate change impacts on the spatial extent of snow-cover in the Australian Alps', in K Green (ed.), Snow: a natural history; an uncertain future, Australian Alps Liaison Committee, Canberra, pp. 195-206.

Williams, D \& Stewart, S 1998, 'Sense of place: an elusive concept that is finding a home in ecosystem management', Journal of Forestry, vol. 96, no. 5, pp. 18-23.

Wyborn, C \& Cleland, D in press, 'Fences and windows: using visual methods to explore conflicts in land and seascape management', in VA Brown, JA Harris \& JY Russell (eds), Tackling wicked problems: through the transdisciplinary imagination, Earthscan, London. 